\title{
Loktanella agnita sp. nov. and Loktanella rosea sp. nov., from the north-west Pacific Ocean
} Correspondence
Elena P. Ivanova
eivanova@swin.edu.au

\author{
Elena P. Ivanova, ${ }^{1,2}$ Natalia V. Zhukova, ${ }^{3}$ Anatoly M. Lysenko, ${ }^{4}$ \\ Nataliya M. Gorshkova, ${ }^{2}$ Alexander F. Sergeev, ${ }^{5}$ Valery V. Mikhailov ${ }^{2}$ \\ and John P. Bowman ${ }^{6}$
}

\author{
${ }^{1}$ Swinburne University of Technology, PO Box 218, Hawthorn, VIC 3122, Australia \\ ${ }^{2}$ Pacific Institute of Bioorganic Chemistry of the Far-Eastern Branch of the Russian Academy \\ of Sciences, Pr. 100 Let Vladivostoku 159, 690022 Vladivostok, Russian Federation \\ ${ }^{3}$ Institute of Marine Biology of the Far-Eastern Branch of the Russian Academy of Sciences, \\ 690041 Vladivostok, Russian Federation \\ ${ }^{4}$ Institute of Microbiology of the Russian Academy of Sciences, 117811 Moscow, Russian \\ Federation \\ ${ }^{5}$ Pacific Oceanological Institute of the Far-Eastern Branch of the Russian Academy of \\ Sciences, Baltiiskaya Str. 43, 690017 Vladivostok, Russian Federation \\ ${ }^{6}$ School of Agricultural Science, University of Tasmania, Private Bag 54, Hobart, Tasmania \\ 7001, Australia
}

The genus Loktanella was created in 2004 to accommodate three species, Loktanella fryxellensis, Loktanella salsilacus and Loktanella vestfoldensis, of heterotrophic 'Alphaproteobacteria' isolated from microbial mat samples collected from different Antarctic lakes (Van Trappen et al., 2004). One more species, Loktanella hongkongensis, was recently added to the genus (Lau et al., 2004).

The GenBank/EMBL/DDBJ accession numbers for the 16S rRNA gene sequences of Loktanella agnita $\mathrm{R} 10 \mathrm{SW} \mathrm{5}^{\mathrm{T}}$ and Loktanella rosea Fg36 $^{\top}$ are AY682198 and AY682199, respectively.

A supplementary table showing the polar lipid and cellular fatty acid compositions of Loktanella agnita and Loktanella rosea is available in IJSEM Online.
This study extends our previous investigations of the biodiversity of marine proteobacteria from the Sea of Japan, north-west Pacific Ocean, and other geographical locations (Ivanova et al., 1996, 1998, 2000, 2004a, b). During isolation studies, bacteria of different taxonomic groups, including Shewanella, Marinobacter, Halomonas and Pseudoalteromonas, have been isolated (E. P. Ivanova, unpublished data; Ivanova et al., 2001, 2004b). Here, we describe two Roseobacter-Ruegeria-Sulfitobacter-like phenotypes that appeared to represent novel members of the genus Loktanella (Van Trappen et al., 2004). Strains examined in this study were isolated in November 2000 from water (salinity, $32 \%$; temperature, $13 \cdot 6{ }^{\circ} \mathrm{C}$ ) samples of two different horizons, from the first metre below the 
surface and from 1-2 $\mathrm{m}$ from the bottom (a varying depth of 9-13 m), in Chazhma Bay, Gulf of Peter the Great, Sea of Japan, Pacific Ocean, by using a standard hydrological plastic bathometer. Sample-handling and isolation procedures were described elsewhere (Ivanova et al., 1996, 2004a, b).

Phenotypic properties used for characterization of the new isolates were investigated by using standard procedures (Smibert \& Krieg, 1994) and as described elsewhere (Ivanova et al., 1996, 1998). To study the physiological properties, bacteria were grown under optimal conditions at $22-24^{\circ} \mathrm{C}$. Motility was studied in hanging-drop preparations. The following physiological and biochemical properties were examined: oxidation/fermentation of glucose (Hugh \& Leifson, 1953), Gram stain, reduction of nitrate and nitrite, catalase [with $5 \%(\mathrm{v} / \mathrm{v}) \mathrm{H}_{2} \mathrm{O}_{2}$ ] and oxidase (Kóvacs, 1956) activities, gelatin liquefaction, arginine dihydrolase, lysine decarboxylase, ornithine decarboxylase, poly- $\beta$-hydroxybutyrate and acetoin production (VogesProskauer test), sodium requirement $[0,1,3,6,8,10,12$ and $15 \%(\mathrm{w} / \mathrm{v}) \mathrm{NaCl}$, indole and $\mathrm{H}_{2} \mathrm{~S}$ production and the ability to hydrolyse starch, Tween 80 , casein, DNA and agar. The temperature range for growth was examined on marine agar incubated at $2,4,10,30,35,37$ and $42^{\circ} \mathrm{C}$. The haemolytic activity of the strains studied was detected on blood agar comprising $40 \mathrm{~g}$ trypticase-soy agar $\mathrm{l}^{-1}, 50 \mathrm{ml}$ sheep blood and $950 \mathrm{ml}$ water. Oxidative utilization of 95 carbon sources was tested by using Biolog GN Microplates (Rüger \& Krambeck, 1994) as described elsewhere (Ivanova et al., 1998).

For analysis of phospholipids and fatty acids, the strains were grown at $28^{\circ} \mathrm{C}$ on marine agar 2216 . After 48 h growth, cells were harvested. The lipids were extracted by a modification of the method of Bligh \& Dyer (1959). Polar lipids were separated by two-dimensional microthin-layer chromatography in solvent systems described by Vaskovsky \& Terekhova (1979). The detection and identification of lipids and fatty acids were performed as described elsewhere (Ivanova et al., 2005). Phosphatidylglycerol, diphosphatidylglycerol and phosphatidylcholine were the major phospholipid constituents. In strain $\mathrm{R} 10 \mathrm{SW} 5^{\mathrm{T}}$ and the four pinkish strains, they respectively accounted for: 58 and $69-79 \% ; 11$ and $0-6 \%$; and 28 and $22-26 \%$ of the total phospholipids, respectively. In addition, phosphatidylethanolamine was detected in strain R10SW5 ${ }^{\mathrm{T}}(3 \%)$ and in trace amounts in strains Fg36 ${ }^{\mathrm{T}}, \mathrm{Fg} 1, \mathrm{Fg} 116$ and Fg117. The major cellular fatty acids for R $10 \mathrm{SW} 5^{\mathrm{T}}$ and the four pinkish strains, respectively, comprised the following: $16: 0,8 \cdot 7$ and $9-12 \% ; 18: 1 \omega 9,2 \cdot 6$ and $5-7 \% ; 18: 1 \omega 7,79$ and $68-72 \%$ (interstrain variations in cellular lipid composition are shown in the Supplementary Table, available in IJSEM Online).

DNA was isolated from the strains by following the method of Marmur (1961). The G+C content of the DNA was determined by using the thermal-denaturation method (Marmur \& Doty, 1962). The DNA G + C content for strain
R10SW5 ${ }^{\mathrm{T}}$ was $59 \cdot 1 \mathrm{~mol} \%$ and those for the four pinkish strains ranged from 60.5 to $61.8 \mathrm{~mol} \%$. DNADNA hybridization was performed spectrophotometrically and initial renaturation rates were recorded as described elsewhere (Marmur \& Doty, 1962; De Ley et al., 1970). DNA-DNA hybridization data revealed high interspecies levels of DNA relatedness among the four pinkish strains (96-98\%), indicating that they represent a single genospecies (Wayne et al., 1987). DNA from the type strain of L. vestfoldensis, LMG $22003^{\mathrm{T}}$, showed intrageneric relatedness with R10SW5 ${ }^{\mathrm{T}}(35 \%)$. These data indicated clearly that R10SW5 ${ }^{\mathrm{T}}$ constituted a distinct Loktanella species (Wayne et al., 1987; Stackebrandt \& Goebel, 1994).

The small-subunit rRNA genes were sequenced as described elsewhere (Ivanova et al., 2004b). 16S rRNA gene sequences of novel Loktanella species were aligned and analysed in the program BioEdit by using PHYLIP version $3.57 \mathrm{c}$ (Felsenstein, 1993). DNADIST was used to determine sequence similarities by using the maximum-likelihood algorithm option. Phylogenetic trees were constructed with maximum-likelihood distances and joined by neighbour joining using the program NEIGHBOR. The outgroups on the Loktanella trees were Albidovulum inexpectatum and Rhodobacter veldkampii. According to phylogenetic analysis (Fig. 1), strains R10SW5 ${ }^{\mathrm{T}}$ and $\mathrm{Fg} 36^{\mathrm{T}}$, Fg1, Fg116 and Fg117 (the latter four sequences were almost identical, with sequence dissimilarity of $<0.3 \%$, to that of the type strain, therefore only $\mathrm{Fg} 36^{\mathrm{T}}$ and $\mathrm{Fg} 1$ were included in the resulting tree) formed separate clusters within species of the genus Loktanella. The most similar sequence was that

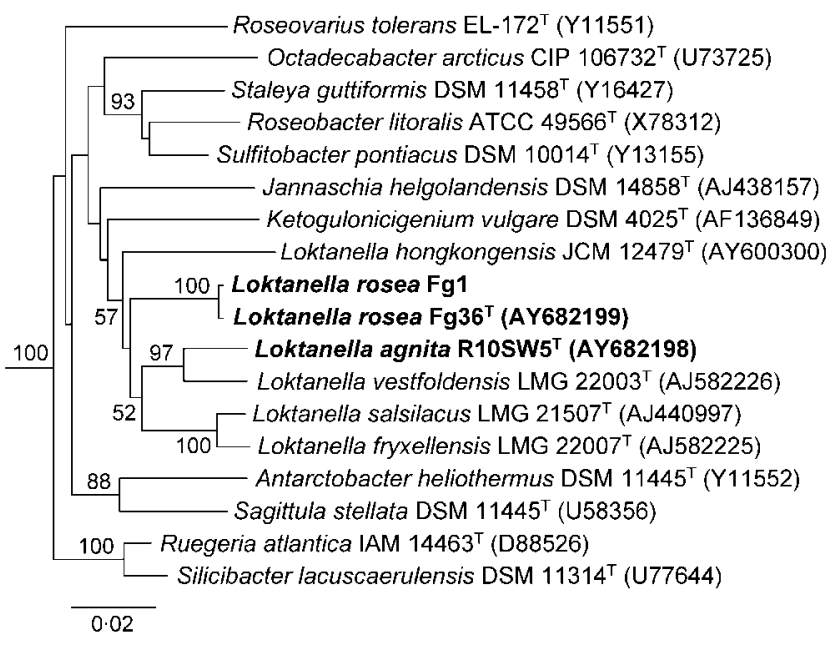

Fig. 1. Phylogenetic position of Loktanella agnita and Loktanella rosea according to 16S rRNA gene sequence analysis. The tree is based on maximum-likelihood distances and joined by neighbour joining; bootstraps are from 500 replications and only values $>50 \%$ are shown. Outgroups were Albidovulum inexpectatum and Rhodobacter veldkampii. 
of L. vestfoldensis, sharing 97 and $95 \%$ 16S rRNA gene sequence similarity with strains $\mathrm{R} 10 \mathrm{SW} 5^{\mathrm{T}}$ and $\mathrm{Fg} 36^{\mathrm{T}}$, respectively, followed by the remaining species with validly published names. Even though the $16 \mathrm{~S}$ rRNA gene sequence of L. vestfoldensis showed $97 \%$ similarity to that of R10SW5 ${ }^{\mathrm{T}}$, DNA relatedness between the two strains was found to be low (35\%), which is in agreement with previous findings that bacteria that differ by $>2.5 \%$ at the $16 \mathrm{~S}$ rRNA gene sequence level are unlikely to exhibit more than 60-70\% DNA-DNA hybridization (Stackebrandt \& Goebel, 1994; Keswani \& Whitman, 2001; Rosselló-Mora \& Amann, 2001). The new sequences of R10SW5 ${ }^{\mathrm{T}}$ and $\mathrm{Fg} 36^{\mathrm{T}}$ shared only $95 \% 16 \mathrm{~S}$ rRNA gene sequence similarity with each other. Notably, the two new phenotypes and the four existing species of the genus Loktanella all grouped together, with rather low bootstrap values (approx. $57 \%$ ). The group of four pinkish strains clearly represents an individual lineage and does not form a robust cluster with any other species of the genus (supported by the low bootstrap values). Based on these results, we could consider that they represent a species of a novel genus. However, we believe that, at the current stage, there are not enough differentiating phenoand chemotypic characteristics to support such a proposal. Overall, our phylogenetic analysis indicated that the current taxonomic interpretation of the grouping of species of Loktanella and those of the genera Roseobacter, Sulfitobacter, Oceanibulbus, Staleya, Silicibacter, Ruegeria and some other related 'Alphaproteobacteria' remains unsatisfactory (Rüger \& Höfle, 1992; Uchino et al., 1998, 1999; Söller et al., 2000) and requires further phylogenetic analyses employing more housekeeping genes.

In addition to phylogenetic and genetic evidence, bacteria of the novel species can be distinguished from other Loktanella species by a number of phenotypic traits (Table 1). For example, in contrast to L. vestfoldensis and other species of the genus, except for $L$. salsilacus in which colony pigmentation is beige, strain $\mathrm{R} 10 \mathrm{SW} 5^{\mathrm{T}}$ is non-pigmented, exhibits a weak oxidase reaction and requires $\mathrm{NaCl}$ at a limited range of 3-6\% for growth, whereas the four pinkish strains are essentially identical in their phenotypic characteristics, but differ from $L$. hongkongensis by lack of brown diffusible pigment and lack of ability to grow at $44^{\circ} \mathrm{C}$ or in the presence of $14 \% \mathrm{NaCl}$; they also differ from other species by their obligate requirement for $\mathrm{NaCl}$ and halophilicity (ability to grow in $12 \% \mathrm{NaCl}$ ). Chemotaxonomically, all species of the genus possess the characteristic fatty acid $18: 1 \omega 7$ at $68-87 \%$ of total fatty acids. Nonetheless, a distinct species-specific pattern is observed for the new bacteria. Whilst the high proportion of $18: 1 \omega 7$ is retained, strain R10SW ${ }^{\mathrm{T}}$ can be distinguished from other species of the genus by a greater proportion of the saturated fatty acids $14: 0,15: 0$ and $16: 0$, and of $14: 1$. The four strains of the other species, Fg36 ${ }^{\mathrm{T}}, \mathrm{Fg} 1, \mathrm{Fg} 116$ and $\mathrm{Fg} 117$, can be distinguished by a lower proportion of $18: 1 \omega 7,10: 03-\mathrm{OH}$ and $12: 03-\mathrm{OH}$, and a greater proportion of $16: 0$. On the basis of these results, two novel species of the genus Loktanella are proposed: Loktanella agnita sp. nov. and Loktanella rosea sp. nov.

Table 1. Characteristics that differentiate Loktanella agnita and Loktanella rosea from other species of the genus

Taxa: 1, L. agnita; 2, L. rosea; 3, L. fryxellensis; 4, L. hongkongensis; 5, L. salsilacus; 6, L. vestfoldensis. All species are catalase-positive. W, Weakly positive reaction; $\mathrm{V}$, variable reaction depending on strain; ND, no data available.

\begin{tabular}{|c|c|c|c|c|c|c|}
\hline Characteristic & 1 & 2 & $3^{*}$ & $4 \dagger$ & $5^{*}$ & $6^{*}$ \\
\hline DNA G $+C$ content $(\mathrm{mol} \%)$ & 59 & 61 & 66 & 66 & $59-60$ & $62-63$ \\
\hline Colony pigmentation & Whitish & Pink & Pink-beige & Pink-white & Beige & Pink \\
\hline Oxidase & $\mathrm{W}$ & + & + & + & + & + \\
\hline \multicolumn{7}{|l|}{ Growth on: } \\
\hline Temperature range for growth $\left({ }^{\circ} \mathrm{C}\right)$ & $8-35$ & $4-35$ & $5-25$ & $8-44$ & $5-30$ & $5-37$ \\
\hline $\mathrm{NaCl}$ range for growth (\%) & $3-6$ & $1-12$ & $0-5$ & $2-14$ & $0-10$ & $0-10$ \\
\hline Reduction of nitrate to nitrite & $\mathrm{W}$ & - & - & - & - & - \\
\hline \multicolumn{7}{|l|}{ Production of: } \\
\hline Lipase (Tween 80) & - & $\mathrm{w}$ & + & - & + & + \\
\hline
\end{tabular}

*Data from Van Trappen et al. (2004).

$\dagger$ Data from Lau et al. (2004). 


\section{Description of Loktanella agnita sp. nov.}

Loktanella agnita (ag.ni'ta. L. fem. part. adj. agnita recognized).

Rod-shaped cells, single, about $0 \cdot 7-0.9 \mu \mathrm{m}$ in diameter. Gram-negative. Non-motile. Chemo-organotroph with respiratory metabolism. Colonies are uniformly round, 1-3 $\mathrm{mm}$ in diameter, regular, convex, smooth and whitish after incubation for 48-74 h on marine agar. No diffusible pigment is released into the medium. Endospores are not formed. $\mathrm{Na}^{+}$or sea water is required for growth. Catalase reaction is positive, but oxidase reaction is only weakly positive. Growth occurs in media with 3-6\% $\mathrm{NaCl}$. Temperature range for growth is $8-35^{\circ} \mathrm{C}$, with an optimum at $25^{\circ} \mathrm{C}$. No growth is detected at $37^{\circ} \mathrm{C}$. The $\mathrm{pH}$ for growth ranges from $6 \cdot 0$ to $10 \cdot 0$, with an optimum at $7 \cdot 5-8 \cdot 0$. Does not decompose gelatin, agar, starch, casein, laminarin, chitin, Tween 80 or DNA. Negative for indole, $\mathrm{H}_{2} \mathrm{~S}$, poly- $\beta$ hydroxybutyrate and acetoin production, arginine dihydrolase, lysine decarboxylase and ornithine decarboxylase. Weakly reduces nitrate to nitrite. Non-haemolytic. Exhibits only a limited ability to utilize carbon sources, utilizing glycyl L-glutamic acid, alaninamide and glycyl L-aspartic acid (according to Biolog). The main cellular fatty acid is 18: $1 \omega 7$ (approx. $77 \%$ ). The DNA G $+\mathrm{C}$ content is $59 \cdot 1 \mathrm{~mol} \%$.

Isolated from sea water of Chazma Bay, Sea of Japan, Pacific Ocean. The type strain is R $10 \mathrm{SW} 5^{\mathrm{T}}\left(=\mathrm{KMM} 3788^{\mathrm{T}}=\mathrm{CIP}\right.$ $\left.107883^{\mathrm{T}}\right)$.

\section{Description of Loktanella rosea sp. nov.}

Loktanella rosea (ro.se' a. L. fem. adj. rosea rose-coloured or rosy, referring to the pinkish colour of the colonies).

Rod-shaped cells, single, about $0 \cdot 7-0 \cdot 9 \mu \mathrm{m}$ in diameter. Gram-negative. Non-motile. Chemo-organotroph with respiratory metabolism. Colonies are uniformly round, 1-3 $\mathrm{mm}$ in diameter, regular, convex, smooth, transparent and pinkish after incubation for $48-74 \mathrm{~h}$ on marine agar. No diffusible pigment is released into the medium. Endospores are not formed. Oxidase- and catalase-positive. $\mathrm{Na}^{+}$or sea water is required for growth. Growth occurs in media with $1-12 \% \mathrm{NaCl}$. Mesophilic. Temperature range for growth is $4-35^{\circ} \mathrm{C}$, with an optimum at $25^{\circ} \mathrm{C}$. No growth is detected at $37^{\circ} \mathrm{C}$. The $\mathrm{pH}$ for growth ranges from 6.0 to $10 \cdot 0$, with an optimum at $7 \cdot 5-8 \cdot 0$. Does not decompose gelatin, agar, starch, casein, laminarin, chitin or DNA. Tween 80 is utilized weakly. Negative for indole, $\mathrm{H}_{2} \mathrm{~S}$, poly$\beta$-hydroxybutyrate and acetoin production, arginine dihydrolase, lysine decarboxylase and ornithine decarboxylase. Does not reduce nitrate to nitrite. Non-haemolytic. Exhibits only a limited ability to utilize carbon sources, utilizing glucuronamide, alaninamide and L-alanylglycine (according to Biolog). Phosphatidylglycerol, diphosphatidylglycerol and phosphatidylcholine are the major phospholipids. The main cellular fatty acid is 18:1 $1 \omega 7$ (approx. 77\%). The G $+C$ content of the DNA is $60 \cdot 5-61 \cdot 8$ mol\%.
Isolated from sediments of Chazma Bay, Sea of Japan, Pacific Ocean. The type strain is $\mathrm{Fg}^{36^{\mathrm{T}}}$ (=KMM $6003^{\mathrm{T}}=$ CIP $107851^{\mathrm{T}}=$ LMG $22534^{\mathrm{T}}$ ).

\section{Acknowledgements}

This study was partially supported by funds from the Australian Research Council (ARC), grant no. 02-04-49517 from the Russian Foundation for Basic Research, grant no. 2-2.16 from the Federal Agency for Science and Innovations of the Ministry for Education and Science of the Russian Federation and a grant from the Presidium of the Russian Academy of Sciences 'Molecular and Cell Biology'.

\section{References}

Bligh, E. G. \& Dyer, W. J. (1959). A rapid method of total lipid extraction and purification. Can J Med Sci 37, 911-917.

De Ley, J., Cattoir, H. \& Reynaerts, A. (1970). The quantitative measurement of DNA hybridization from renaturation rates. Eur J Biochem 12, 133-142.

Felsenstein, J. (1993). PHYLIP (phylogeny inference package), version 3.5c. Department of Genome Sciences, University of Washington, Seattle, USA.

Hugh, R. \& Leifson, E. (1953). The taxonomic significance of fermentative versus oxidative metabolism of carbohydrates by various gram-negative bacteria. J Bacteriol 66, 24-26.

Ivanova, E. P., Kiprianova, E. A., Mikhailov, V. V., Levanova, F. G., Garagulya, A. G., Gorshkova, N. M., Yumoto, N. \& Yoshikawa, S. (1996). Characterization and identification of marine Alteromonas nigrifaciens strains and emendation of the description. Int J Syst Bacteriol 46, 223-228.

Ivanova, E. P., Kiprianova, E. A., Mikhailov, V. V. \& 8 other authors (1998). Phenotypic diversity of Pseudoalteromonas citrea from different marine habitats and emendation of the description. Int J Syst Bacteriol 48, 247-256.

Ivanova, E. P., Romanenko, L. A., Chun, J. \& 7 other authors (2000). Idiomarina gen. nov., comprising novel indigenous deep-sea bacteria from the Pacific Ocean, including description of two species, Idiomarina abyssalis sp. nov. and Idiomarina zobellii sp. nov. Int J Syst Evol Microbiol 50, 901-907.

Ivanova, E. P., Sawabe, T., Gorshkova, N. M., Svetashev, V. I., Mikhailov, V. V., Nicolau, D. V. \& Christen, R. (2001). Shewanella japonica sp. nov. Int J Syst Evol Microbiol 51, 1027-1033.

Ivanova, E. P., Gorshkova, N. M., Sawabe, T. \& 8 other authors (2004a). Sulfitobacter delicatus sp. nov. and Sulfitobacter dubius sp. nov., respectively from a starfish (Stellaster equestris) and sea grass (Zostera marina). Int J Syst Evol Microbiol 54, 475-480.

Ivanova, E. P., Nedashkovskaya, O. I., Sawabe, T., Zhukova, N. V., Frolova, G. M., Nicolau, D. V., Mikhailov, V. V. \& Bowman, J. P. (2004b). Shewanella affinis sp. nov., isolated from marine invertebrates. Int J Syst Evol Microbiol 54, 1089-1093.

Ivanova, E. P., Onyshchenko, O. M., Christen, R., Lysenko, A. M., Zhukova, N. V., Shevchenko, L. S. \& Kiprianova, E. A. (2005). Marinomonas pontica sp. nov., isolated from the Black Sea. Int J Syst Evol Microbiol 55, 275-279.

Keswani, J. \& Whitman, W. B. (2001). Relationship of $16 \mathrm{~S}$ rRNA sequence similarity to DNA hybridization in prokaryotes. Int J Syst Evol Microbiol 51, 667-678.

Kóvacs, N. (1956). Identification of Pseudomonas pyocyanea by the oxidase reaction. Nature 178, 703. 
Lau, S. C. K., Tsoi, M. M. Y., Li, X., Plakhotnikova, I., Wu, M., Wong, P.-K. \& Qian, P.-Y. (2004). Loktanella hongkongensis sp. nov., a novel member of the $\alpha$-Proteobacteria originating from marine biofilms in Hong Kong waters. Int J Syst Evol Microbiol 54, 2281-2284.

Marmur, J. (1961). A procedure for the isolation of deoxyribonucleic acid from microorganisms. J Mol Biol 3, 208-218.

Marmur, J. \& Doty, P. (1962). Determination of the base composition of deoxyribonucleic acid from its thermal denaturation temperature. J Mol Biol 5, 109-118.

Rosselló-Mora, R. \& Amann, R. (2001). The species concept for prokaryotes. FEMS Microbiol Rev 25, 39-67.

Rüger, H. J. \& Höfle, M. G. (1992). Marine star-shaped-aggregateforming bacteria: Agrobacterium atlanticum sp. nov.; Agrobacterium meteori sp. nov.; Agrobacterium ferrugineum sp. nov., nom. rev.; Agrobacterium gelatinovorum sp. nov., nom. rev.; and Agrobacterium stellulatum sp. nov., nom. rev. Int J Syst Bacteriol 42, 133-143.

Rüger, H.-J. \& Krambeck, H.-J. (1994). Evaluation of the BIOLOG substrate metabolism system for classification of marine bacteria. Syst Appl Microbiol 17, 281-288.

Smibert, R. M. \& Krieg, N. R. (1994). Phenotypic characterization. In Methods for General and Molecular Bacteriology, pp. 607-655. Edited by P. Gerhardt, R. G. E. Murray, W. A. Wood \& N. R. Krieg. Washington, DC: American Society for Microbiology.

Söller, R., Hirsch, P., Blohm, D. \& Labrenz, M. (2000). Differentiation of newly described Antarctic bacterial isolates related to Roseobacter species based on 16S-23S rDNA internal transcribed spacer sequences. Int J Syst Evol Microbiol 50, 909-915.
Stackebrandt, E. \& Goebel, B. M. (1994). Taxonomic note: a place for DNA-DNA reassociation and 16S rRNA sequence analysis in the present species definition in bacteriology. Int J Syst Bacteriol 44, 846-849.

Uchino, Y., Hirata, A., Yokota, A. \& Sugiyama, J. (1998). Reclassification of marine Agrobacterium species: proposals of Stappia stellulata gen. nov., comb. nov., Stappia aggregata sp. nov., nom. rev., Ruegeria atlantica gen. nov., comb. nov., Ruegeria gelatinovora comb. nov., Ruegeria algicola comb. nov., and Ahrensia kieliense gen. nov., sp. nov., nom. rev. J Gen Appl Microbiol 44, 201-210.

Uchino, Y., Hirata, A., Yokota, A. \& Sugiyama, J. (1999). In Validation of the Publication of New Names and New Combinations Previously Effectively Published Outside the IJSB, List no. 68. Int J Syst Bacteriol 49, 1-3.

Van Trappen, S., Mergaert, J. \& Swings, J. (2004). Loktanella salsilacus gen. nov., sp. nov., Loktanella fryxellensis sp. nov. and Loktanella vestfoldensis sp. nov., new members of the Rhodobacter group, isolated from microbial mats in Antarctic lakes. Int J Syst Evol Microbiol 54, 1263-1269.

Vaskovsky, V. E. \& Terekhova, T. A. (1979). HPTLC of phospholipid mixtures containing phosphatidylglycerol. J High Resolut Chromatogr Chromatogr Commun 2, 671-672.

Wayne, L. G., Brenner, D. J., Colwell, R. R. \& 9 other authors (1987). International Committee on Systematic Bacteriology. Report of the ad hoc committee on reconciliation of approaches to bacterial systematics. Int J Syst Bacteriol 37, 463-464. 